\title{
老人の大腿骨頸部骨折の合併症についての検討
}

\author{
大车田記念病院 整形外科 \\ 松下 和 徳 \\ 佐賀医科大学 整形外科 \\ 忽 那 龍 雄 \\ 小柳病院 整形外科 \\ 南尚次
}

\section{A Study of Complications in Eldery Patients Treated for Femoral Neck Fracture}

by

\author{
Kazunori Matsushita \\ Division of Orthopedic Surgery, Omuta Memorial Hospital, Fukuoka, Japan \\ Tatsuo Kutsuna \\ Division of Orthopedic Surgery, Saga Medical School, Saga, Japan \\ Hisatsugu Minami \\ Division of Orthopedic Surgery, Koyanagi Hospital, Saga, Japan
}

\begin{abstract}
The study of complications in 156 patients over the age of 65 years old with femoral neck fracture was undertaken. Of these 156 fractures, 141 cases were operated and 15 cases were treated consevatively.

The results were as follows.

1. General physical complications were observed in 98 cases $(62 \%)$ on admission and most frequently occurred in cases of 70-79 years of age.

2. Mental deterioration was found in 32 cases $(21 \%)$ and the frequency of senile dementia depended upon aging.

3. The effective factors for walking ability on discharge were mental disturbance and age.

4. All of the dead cases were accompanied with severe physical complications on admission.
\end{abstract}

\section{はじめに}

近年, 人口の高令化に伴い大腿骨頸部骨折は増加傾 们にある，老人の大腿尚项部肖折の治潦に際しては， 骨折以外に高頻度に身体的・精神的合併症を有してお り, 特に, 入院時に全身状態の把握と改善をはかる必 要がある，そこで，私達が治潦を行なった 65 才以上 の大腿骨頸部骨折患者について，その身体的合併症や 精神的合併症を調查し, 問題点を検討したので文献的 考察を加えて報告する。

\section{対象並びに方法}

過去 8 年間に私達が治療した 65 才以上の大腿骨頸 部骨折患者は 156 例（男性 28 例, 女性 128 例）で, 年令は 65 才より 96 才（平均 78.7 才）であった。 肖 折型は，内側骨折が 75 例（男性 11 例, 女性 64 例）で, それらの半均年令は 77.3 才，外倒肖折が 81 例（男性. 17 例, 女性 64 例）で, それらの平均年令は 80.1 才 であった。

対象症例に対する治療法は, 保存療法が 15 例, 手 術潦法が 141 例であった。このうち, 内側骨折は主に 人:頭置換術を, 外側骨折は compression hip screw 
による骨接合術を施行した。

以上の症例について，歩行能力は（a）独歩または $\mathrm{T}$ 杖歩行が可能なもの, (b ) 両松葉杖歩行が可能な もの，（c）車いす移動が可能なもの，（d）寝たきり のものに分類し，身体的合併症は(1)心疾患(2)高血圧症 (3)肺疾患(4)片麻疩を含む脳血管障害(5) RA や DM など の全身合併症の有無について調査した。また，精神的 合併症は長谷川式簡易知能検査法によって分類し，入 院時および入院期間中の老年施呆の出現や増悪の有 無,さらに，受傷後または術後の急性錯乱状態 (acuteco-nfusional states, ACS と略す) の出現につ いて調查し,これらと受傷前および煺院時歩行能力と の関連性について検討した。ささらに, 死亡例について 合併症や死因について調査した。

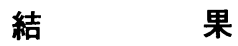

\section{1）歩行能力}

受傷前の歩行能力は, 独歩又は $\mathrm{T}$ 杖歩行が可能で あったもの 148 例, 峌松葉杖歩行であったもの 2 例, 寝たきり 6 例であった，退院時歩行能力は歩行可能で あったものが 114 例（73\%）で，歩行不能例は 42 例 でこのうち車いす移動可能なものが 34 例で死亡例が 8 例であった（図 1 ).

2) 身体的合併症

入院時身体的合併症は全例の $62 \%$ (97 例)に存在し， その内訳は高血庄症 44 例，心疾患 42 例，脳血管障害 12 例, 肺疾患 11 例, DM 9 例, RA 8 例であった。 れらの年代別有病率は, 70 才代が 80 例中 59 例 $(74 \%)$

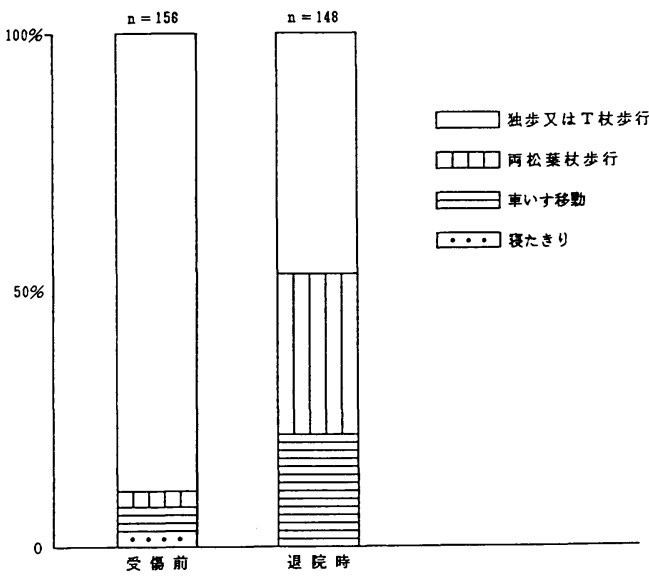

图 1 受湶解と迎院時の歩行能力
で最も高く，次いで 90 才代が 9 例中 5 例 $(56 \%) ， 80$ 才代が 57 例中 28 例 $(50 \%) ， 60$ 才代が 10 例中 5 例 (50\%) であった（図 2 ).

\section{3）精神的合併症}

入院時精神的合併症は，老年痴染が 156 例中 32 例 (21\%) にみられ，年令別では，90才代が 9 例中 3 例 $(33 \%), 80$ 才代が 57 例中 12 例 $(21 \%), 70$ 才代 が 80 例中 16 例 $(20 \%), 60$ 才代が 10 例中 1 例 $(10 \%)$ に認められた。

精神的合併症は入院前までに老年痴朵があった 32 例のうち，入院期間中更に増悪したもの 13 例 $(40 \%)$ ありまた 32 例中，急性錯乱状態（ACS）が出現し たものが 17 例 $(52 \%)$ にみられた。このうち ACSが 改善したのち, 老年痴朵が増悪したものが 17 例中 11 例に認められた。

また，入院時老年痴朵のなかった 124 例では, 老年痴 呆が出現したもの 8 例 ( $7 \%$ ）， ACSの出現したもの が 6 例 $(5 \%), \operatorname{ACS}$ が出現その後老年痴朵が出現し たものが 11 例中 5 例であった（四 3 ）。

4）退院時歩行能力と身体的および精神的合併症と の関連性
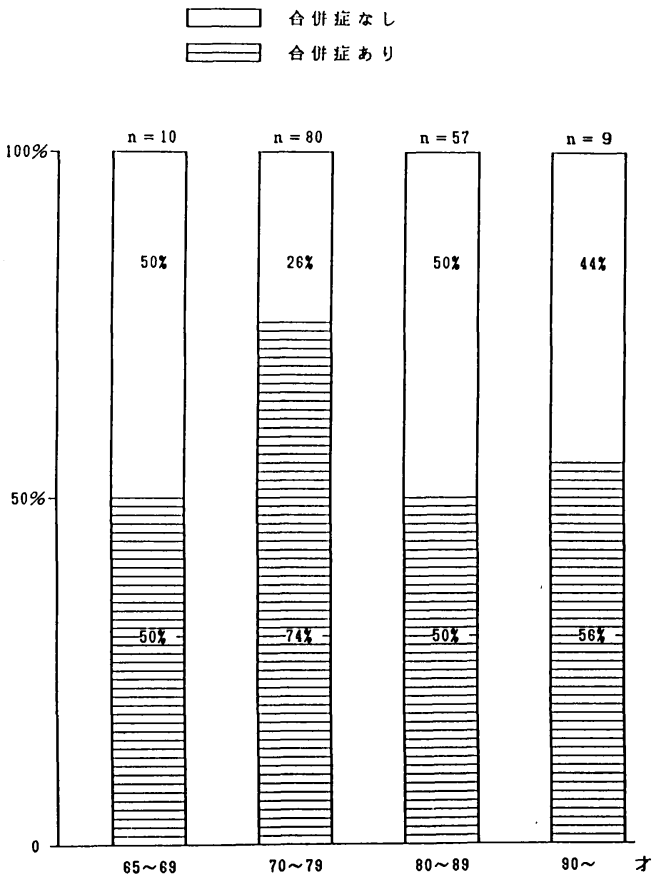

図2年令身体的合併症： 


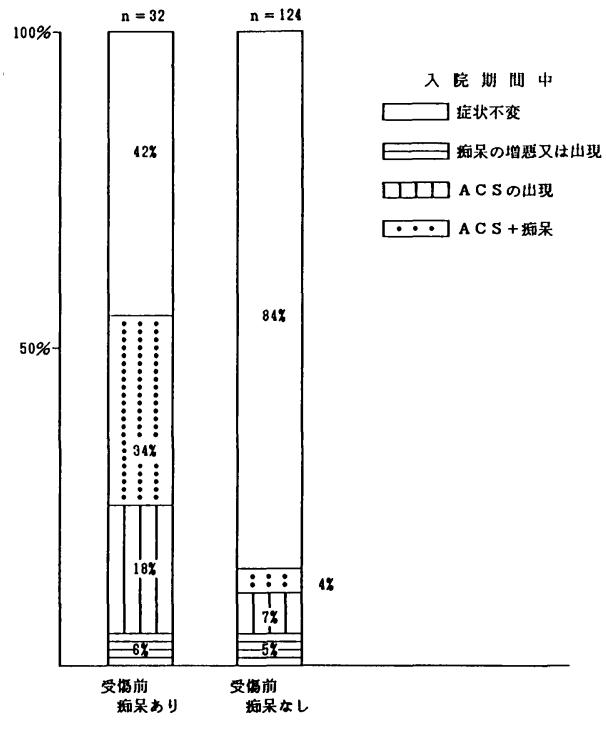

図 3 入院期間中の精神的合併症

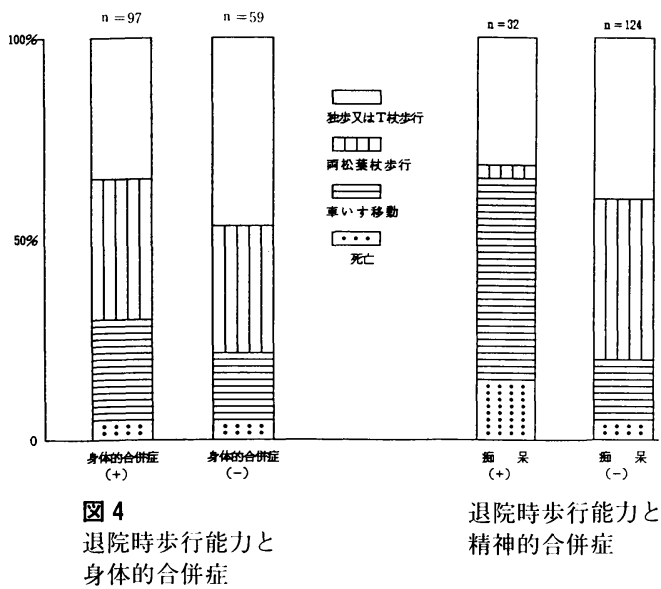

入院時に身体的合併症を有していた 97 例のうち， 退院時歩行可能例は 73 例 $(75 \%)$ で，身体的合併症 のなかった 59 例のうち歩行可能例は 40 例 $(68 \%)$ で あった。

精神的合併症との関連では老年疾呆を有していた 32 例中, 22 例 $(69 \%)$ は歩行不能で, 老年痴呆のなかっ た症例のうち歩行不能となった 24 例 (19\%) と比べて, 明らかに老年痴笨合併症例が, 退院時歩行能力が低下 していた(図4).

5）死亡退院例の検討

死亡退院例は 8 例あり, 全例に入院時すでに慢性心
不全，肺炎など重篤な合併症があった.

また， 8 例中 7 例は入院中肺炎や肺水腫から心不全 を併発し， 1 例は術後に広範囲脳梗塞が出現して死亡 した。これらの症例は高令者で身体的合併症を有する 骨折患者で, 術前に全身状態の改善が出来ず早期手術 ができなかった症例であった。

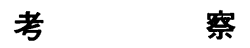

高令者の大腿骨頸部骨折患者の機能的予後に関する 要因としては，年令，入院時全身的合併症や老年痴朵 の有無などが挙げられている1)3)

今回の私達の調査では, 大腿骨頸部骨折患者の受傷 前の身体的合併症の有病率は，62\%であり，これは昭 和 61 年度厚生省生活基礎調査 ${ }^{2)}$ における 65 才以上の 有病率 $64 \%$ とほほ一致して，高率に認められた。し かし, 身体的合併症の有無と退院時歩行能力との関連 性は少なかった。

精神的合併症については，高令者ほど老年痴朵の合 併が多く，入院期間中の ACS の出現頻度も高く，退 院時歩行能力を左右する因子としては，最も大きな要 因であった。また老年痴呆のある患者ほど，入院後の 身体的, 精神的合併症の増悪傾向がある為, 可能なか ぎり早期離床をはかり，脳循環を刺激し，日常生活へ の意欲をたかめたり，手術や訓練などの治療に対する 理解や認識を与え, 医療行為への不安を取り除く努力 が必要であるといえる.

\section{結語}

1）入院時，身体的合併症は $62 \%$ に認められ，70 才代に最も高頻度に合併していた。

2）入院時および入院後の精神的合併症は，156 例 中 51 例 $(33 \%)$ に認められ，入院時老年痴呆があっ たものでは，入院期間中に ACS の出現や老年倁呆の 増悪したものが多かった。

3）退院時歩行能力に影響を及ぼすものは，精神的 合併症状の有無と年令であった。

4）死亡退院例については，全例が入院時すでに重 篤な全身合併症を有していた。

\section{文献}

1）忽删龍雄 他：70才以上の大腿少頸部骨折患者の治 撩上の問題点. 整形外科と災害外科, $34: 4-9,1985$.

2）人口表並びに簡易生命表：国毞衛生の動向，厚生統 計協会, 1987 . 
3）立入克敏 他：合併症からみた老人大腿骨頸部骨折

の予後. 整・災誌, $27: 385-391,1984$.

บen 